\title{
Intensive Board Monitoring and Firm Value: An Empirical Analysis in the Context of Saudi Arabia
}

\author{
Hanan Alhussayen $^{1} \&$ Ridha Shabou ${ }^{1}$ \\ ${ }^{1}$ College of Business Administration, King Saud University, Riyadh, Saudi Arabia \\ Correspondence: Hanan Alhussayen, College of Business Administration, King Saud University, Riyadh, Saudi \\ Arabia. Tel: 966-5-0532-4162.
}

Received: September 29, 2016

Accepted: October 11, $2016 \quad$ Online Published: October 15, 2016

doi:10.5430/ijfr.v7n5p146

URL: http://dx.doi.org/10.5430/ijfr.v7n5p146

\begin{abstract}
This paper intends to examine the role of intensive monitoring by the boards of Saudi listed firms in protecting the firm's resources through analyzing its impact on firm value. Intensive Board Monitoring (IBM) is measured through the independence of the oversight board committees, which is the audit and the nomination and remuneration committees. Whereas the firm's valuation variables that we apply in this paper are Tobin's Q and M-B ratio. The sample understudy covers all the firms listed in the Saudi stock market, except the firms listed in the banking and insurance sectors, over the period 2008 till 2013. The results of the analysis, when we apply the Ordinary Least Square (OLS) approach, reveal that Intensive Board Monitoring (IBM) has a positive and significant impact on firm value. This positive impact is strengthened when we apply the Two Stage Least Square (2SLS) approach, which prove the endogenous nature of the IBM variables.
\end{abstract}

Keywords: Intensive Board Monitoring (IBM), firm value

The managers of the firm can misuse its resources rather than working for the firm's best interest, which causes the principle-agent agency problem (Jensen \& Meckling, 1976; Fama \& Jensen, 1983). Similarly, the principle-principle agency problem results from the pursuance of the controlling shareholders for their own interests rather than considering the interests of the minority shareholders (Claessens, Djankov, \& Lang, 2000). Both of these two agency problems require an effective control mechanism, such as the board of directors, to prevent the managers of the firm and its controlling shareholders from misusing the firm's resources. The effectiveness of the board results from its role, as an internal governance mechanism, in monitoring the actions taken by the managers and controlling shareholders of the firm. The outside board members are considered more effective monitors than the inside board members, as a result, of their independence from the firm (Raheja, 2005). The intensive monitoring by the outside members of the board is proved by previous research to has an impact on the value of the firm (Faleye, Hoitash, \& Hoitash, 2011; Byun, Lee, \& Park, 2013).

Therefore, we intend to define in this paper whether the Intensive Board Monitoring (IBM) by the boards of Saudi listed firms enhances the valuation of these firms. Also we plan to identify whether an endogeneity problem occur in this relationship, where the firm valuation can influence the degree of monitoring intensity by the board. Such analysis is important to measure the effectiveness of the outside members of the boards of Saudi listed firms in monitoring the actions taken by the managers of the firm and its controllers to protect the firm's resources.

Most of the papers that analyze the impact of board independence on the performance of the firm apply the composition ratio of outside directors of the board. This measure of board independence can't identify precisely whether the monitoring role, advisory role, or both roles of the board has an impact on firm's performance (Adams \& Ferreira, 2007; Faleye et al., 2011; Byun et al., 2013). Therefore, we intend in this paper to apply Intensive Board Monitoring (IBM) as a measure of board independence because it can define whether the monitoring role of the board is more effective than its advisory role in improving the value of the firm.

The sample understudy covers a panel data of all the firms listed in the Saudi stock market, except the firms listed in the banking and insurance sectors, over the period 2008 till 2013.

We begin the analysis in this paper by defining the impact of Intensive Board Monitoring (IBM) on firm value, measured by Tobin's Q and M-B ratio, through applying the Ordinary Least Square approach (OLS). After that, we 
consider the endogeneity problem in the relationship between Intensive Board Monitoring and firm value. As the valuation of the firm can be affected by the board monitoring intensity, firm value can also influence the degree of monitoring intensity by the board. Therefore, we apply a simultaneous equation framework to analyze this problem through applying the Two Stage Least Square (2SLS) approach.

The results of the analysis reveal that monitoring intensity by the board has a positive and significant impact on the value of Saudi listed firms. This positive impact is strengthened when we apply the simultaneous equation framework, which proves the existence of the endogeneity problem. These findings prove that in a context, such as the Saudi one, the monitoring functions of the board are more effective in disciplining the firm's managers and controlling shareholders than its advisory functions. This results from the weak regularity system and high concentration of ownership that characterizes the Saudi market, which require higher emphasize on the monitoring functions of the board over its advisory functions.

The rest of the paper is organized as follows: Section one covers the background theory and the concepts we apply in this paper. Section two presents the hypothesis. Section three is devoted to the sources of data and the definition of the variables understudy. Sections four and five present the descriptive statistics and empirical analysis, respectively. Section six concludes the paper.

\section{Theory and Concepts}

This section covers the background theory and the concepts that is related to the board of directors over seven subsections. It begins by identifying the role of the board of directors in the framework of the agency theory in the first subsection. The second subsection talks about the organization of the board and its functions. Whereas the third subsection is dedicated to the trade-off between the monitoring and advisory functions of the board. The fourth and fifth subsections cover the independence of the board and the its oversight committees, respectively. The sixth subsection is devoted to the measures of board independence. The last subsection provides a description about the boards of Saudi listed firms.

\subsection{The Board of Directors in the Framework of Agency Theory}

Both of the principle-agent agency problem and the principle-principle agency problem require an effective monitoring over the firm's managers and controlling shareholders to align their interests with the interests of the shareholders and the minorities, respectively. Therefore, agency theorists propose the role of the board, more specifically, the role of the outside board members in monitoring and controlling the actions of managers and controlling shareholders. According to Fama \& Jensen (1983), the board of directors is a vital internal governance mechanism. The shareholders delegate the control over management to the board. The board members accordingly can evaluate, hire, fire and set the compensations of the firm's managers. The board of directors is defined by Wang \& Dewhirst (1992) as one of the greatest organizational innovations in the field of corporate governance. Also the board of directors is positioned by Jensen (1993) at the top of the internal control system in corporate governance.

The board members, as an internal governance mechanism, can prevent the firm's managers and controllers from taking actions that might harm the shareholders and the minorities, besides that, they can align their interests together. They can do so through their involvement in the approval process of major business decisions and corporate strategy, such as tender offers by acquirers and disposal of assets.

\subsection{The Organization of the Board of Directors and Its Functions}

Maassen (1999) identifies in details two different approaches that is related to the organization of the board of directors, which is: the one-tier board approach and the two-tier board approach. In the one-tier board both of the non-executive and executive directors operate altogether in one layer. In such approach the board can: a) be dominated with non-executive or executive directors, b) separate between the position of the CEO and the chairman of the board or it can combine between them, c) apply board committees, such as the audit and the nomination and remuneration committee. In the two-tier board the non-executive and executive directors operate in two different layers. The upper layer is dominated with non-executive directors who supervise and monitor the managers and controlling shareholders on behalf of stakeholders. Whereas the lower layer is dominated with executive directors who initiate and implement the strategic decisions in the firm. In such board structure, the position of the CEO and the chairman of the board can't be combined together. Also the executive managing directors can't hold a position in the upper supervisory board layer.

The main functions of the board of directors are the monitoring and advisory functions (Hillman \& Dalziel, 2003). The monitoring functions of the board require its members to observe the actions of the firm's managers to align their interests with the interests of the shareholders. Also it requires them to evaluate the performance of the managers and 
define whether those managers are capable of being reassigned again in their positions. While the advisory functions require the board members to use their experience to help the managers in establishing the firm's strategies and policies. These two functions of the board are executed differently in the two board structures. The two-tier board structure separates the monitoring and advisory functions from each other. The executive directors, the inside directors, in the lower layer assess the firm's managers to initiate and implement the strategic decisions in the firm, whereas the non-executive directors, the outside directors, in the upper layer monitor the decisions of the executives. While the one-tier board structure doesn't separate the monitoring and advisory functions from each other. Therefore, higher number of outside board members should be assigned to the one-tier board structure if it's required from the board to emphasize more on its monitoring functions over its advisory functions. The outside members of the board are more independent than the inside members and they can provide the required monitoring over managers and controlling shareholders and offer valuable advises to them (Raheja, 2005).

The above discussion shows that there are two board structures and that the monitoring and advisory functions of the board are held differently in these two structures. Also it reveals that the assignment of the outside members of the board in the one-tier board structure can differ from their assignment in the two-tier board structure.

\subsection{The Trade-off between the Monitoring and Advisory Functions of the Board}

The trade-off between the monitoring and advisory functions of the board depends on the benefits and costs associated with each one of them. Many researchers prove that board monitoring tend to harm firm value in developed markets (Adams \& Ferreira, 2007; Holmstron, 2005; Faleye et al., 2011; Lahlou and Navatte, 2013). This bad influence results from the dominance of the monitoring costs over its benefits, as a result, of hindering the advisory functions of the board. In the study of Adams \& Ferreira (2007), which cover all publicly traded Fortune 500 firms in the year 1998, the researchers define the friendly board as the one in which its members focus more on its advisory functions rather than its monitoring functions. The board members according to this view tend to reduce their monitoring role over the firm's CEOs and emphasize more on their advisory role to encourage the CEOs of the firm to share information with them. The CEOs might be reluctant to share information with the board members if those members emphasize their monitoring role, because sharing such information might threaten their positions in the firm. On the other hand, the CEOs can be encouraged to share information with the board members if they will provide the required advice to the CEOs that can help them to prosper in their positions. In both studies of Faleye et al. and Lahlou and Navatte, that covers the S\&P's 1500 firms, the value of the firm is lower when monitoring intensity of the board is high. These findings are accentuated among the firms that requires more advising by the board. The firms in Faleye et al. study with strong advising needs and their boards practiced intensive monitoring experienced a significant decline in value by $9.5 \%$ compared to a $0.8 \%$ insignificant decline in value for the firms that require low advising. Similarly, the researchers in both studies find that the firms understudy with high monitoring intensity by their boards experienced low acquisition performance and little innovations. The reason behind these findings is that such activities taken by the firm requires strong advising by the board over its monitoring functions.

In emerging markets, monitoring by the board tend to have a positive impact on firm value (Dahya, Dimitrov, and McConnell, 2007; and Byun et al., 2013). In such contexts, the benefits of board monitoring outweighs its costs, as a result, of the weak regularity system and high concentration of ownership that require higher monitoring by the board to control the agency conflict between the managers of the firm and the shareholders and between the controlling shareholders and the minorities (Claessens et al., 2000; Faccio and Lang, 2002). In the cross-country analysis over 799 firms from 22 countries of Dahya et al. (2007), the valuation of the firm, measured by Tobin's Q and market-to-book ratio, is found to be positively correlated with the composition ratio of outside directors in the board, as a result, of strengthening the monitoring functions of the board. This positive correlation strengthen in the countries that has weak protection for their shareholders. Similarly, the study of Byun et al. (2013) reveal that monitoring intensity by the board improve firm value. This positive impact results from the characteristics of the Korean market that has the characteristics of emerging markets. The Korean market is characterized by low development and little protection for shareholder's rights, which requires higher monitoring by the board.

The above findings reveal that the importance of the monitoring functions or the advisory functions of the board depends on the characteristics of the market in which the firm operates. Emerging markets, unlike developed markets, require higher monitoring by the board to overcome the low protection for shareholders and weak development in these markets.

\subsection{The Independence of the Board}

An independent board structure is defined by Davis (1991) as the one that consist of outside directors and in which 
the firm's managers play a minor role in it. In the study of Alagaratnam (2002), the researcher defines three areas in which higher proportion of outside directors can improve the performance of the firm, these three areas are: a) outside directors can develop a code of conduct that is appropriate to the firm's environment in which the executives and employees should follow, b) the professional experience of the outside directors can allow them to develop the appropriate strategies for the firm and to define the opportunities available to the firm and the threats it might face, c) outside directors are effective monitors and evaluators for the executive's performance. Maassen (1999) identifies three design strategies that can enhance the independence of the board and improve the protection of the shareholders from the misuses of managers. These strategies are: a) the separation between the position of the CEO of the firm and the chairman of the board, where these two positions are carried out by different individuals, b) assign more outside directors whom haven't been appointed before in the firm in any managerial position, c) the formation of the board committees that can provide better monitoring over the firm's managers. Large number of researchers prove that boards that are dominated by outside directors tend to improve the performance of the firm (Dahya \& McConnell, 2005; Zheka, 2006; Byun et al., 2013).

The independence of the board is found by Linck, Netter, \& Yang (2008) to increase with firm's complexity, advising benefits, private benefits generated by managers and CEOs duality. While it decreases with monitoring and advising costs, performance of the firm, and the amount of shares held by CEOs and outside directors. These findings prove that higher board independence is required to improve the oversight quality of the board. Similarly, Faleye et al. (2011) find that outside board members can understand the firm and its operations better when they serve in different monitoring committees, which allow them to take better decisions.

These findings prove that higher board independence is required to improve the oversight quality of the board to prevent any possible destroying actions that can be taken by the firm's managers and controlling shareholders.

\subsection{The Oversight Board Committees}

The oversight board committees, such as the audit committee and the nomination and remuneration committee, are considered vital in protecting the interests of shareholders through supervising and monitoring the corporate decisions (Maassen, 1999). These oversight committees are required to enhance the independence of the board of directors, and more specifically the boards with one-tier structure. To be more effective, it must be dominated by outside board members who are independent from the firm's managers and controlling shareholders. Demb \& Neubauer (1992) define that the imbalance in the one-tier board structure can be overcome through the oversight committees. These committees can enhance such imbalance by separating the advisory and monitoring functions of the board. Large number of researchers find that the oversight committees of the board have a positive impact on the corporation (McMullen, 1996; Uzun, Szewczyk, \& Varma, 2004; Chan \& Li, 2008; Amer, Ragab, \& Shehata, 2014). Both of the studies of Uzun et al. and Chan \& Li are conducted on the US market. The study of Uzun et al. discovers that the high independence of the audit and the compensation committees is associated with lower corporate fraud during the period 1978-2001. Similarly, the study of Chan \& Li which covers the top 200 public 500 fortune firms over the year 2000, find that audit committees in which $50 \%$ of its directors are expert independent affect positively on firm value, measured by Tobin's Q. The study of Amer et al. (2014) covers the most active 50 companies listed in the Egyptian stock exchange over the years 2004 till 2012. The researchers find that firm performance, measured by ROA and Tobin's Q, is affected positively and significantly by the independence of the audit committee, where all the members of the committee are outside directors.

Based on the above, the oversight board committees can help on providing the required protection over the minority shareholders through monitoring the actions of the firm's managers and controlling shareholders to prevent them from misusing the firm's resources.

\subsection{Intensive Board Monitoring as a Measure of Board Independence}

Most of the studies that analyze the effectiveness of board independence apply the composition ratio of outside directors as a measure of board independence. Later studies started to question the validity of this measure. These studies start to apply Intensive Board Monitoring (IBM) as a measure of board independence (Adams \& Ferreira, 2007; Faleye et al., 2011; Byun et al., 2013). Board monitoring intensity, measured through the board monitoring committees, can identify more precisely whether the monitoring role, advisory role, or both roles of the board has an impact on firm value, which the composition ratio of outside directors can't do. In Byun et al. study over the period 2005 till 2009, the researchers find a strong positive impact of Intensive Board Monitoring on the valuation of Korean listed firms. This positive impact results from the ineffectiveness of the external governance mechanisms in the Korean context, and the benefits of the board monitoring functions over its advisory functions. In contrast, the 
findings of Faleye et al. reveal that monitoring intensity by the board tend to harm the value of the firms with strong advising needs, as a result, of the dominance of the monitoring costs over its benefits.

Both of these studies differentiate between the monitoring and advisory functions of the board and define which of these functions has more impact on the valuation of the firm. Also it proves that intensive monitoring by the board is a more precise measure for board independence than the composition ratio of outside directors.

\subsection{The Boards of Saudi Listed Firms}

In the context of Saudi Arabia, the boards of Saudi listed firms are all considered one-tier boards. In the one-tier board style, both of the monitoring and advisory functions are executed by the board members at the same layer. Paragraph (a) of Article (10) of the board of directors part of the Corporate Governance regulations, issued by the board of the Capital Market Authority (CMA), states that: "Among the main functions of the board is approving the strategic plans and main objectives of the company and supervising their implementation" (CG regulations, p. 19). Based on this paragraph the board members in Saudi listed firms are responsible for approving the strategic plans of the firm and its main objectives, which is considered part of the advisory functions of the board. Whereas the supervision of the implementation of these strategic plans and objectives are considered part of the monitoring functions of the board.

Combining between these two functions of the board require higher independence by the boards of Saudi listed firms to strengthen their monitoring role over their advisory role. The focus on the monitoring functions of the board in a context such as the Saudi one is required, as a result, of the weak regularity system and high concentration of ownership that require higher monitoring by the board over the firm's managers and controlling shareholders to prevent them from harming the minorities' interests.

The Board of the Capital Market Authority (CMA) issued the Corporate Governance (CG) regulations in November, 2006, based on the Capital Market Law issued by Royal Decree No. M/30 dated 2/6/1424H. The board of directors part of these regulations encourages the independence of the board through mandating all Saudi listed firms to assign independent and non-executive directors in their boards of directors to strengthen the monitoring functions of the board, based on resolution Number (1- 36 -2008) Dated 12/ $11 / 1429 \mathrm{H}$ corresponding to 10/ $11 / 2008 \mathrm{G}$. Besides that, the audit committee and the nomination and remuneration committee become mandatory to apply by Saudi listed firms at the end of the year 2008 and the end of the year 2010, respectively, to strengthen the monitoring function of the board because the focus of these two committees is on the monitoring functions rather than the advisory function.

The above facts about the boards of Saudi listed firms reveal the importance of the monitoring functions of these boards over their advisory functions. This results from the low development and weak regularity system in the Saudi market, which require high monitoring over the firm's managers and controlling shareholders to prevent them from misusing the firm's resources and harming the minorities' interests.

\section{Hypothesis}

This section introduces the hypothesis of this study, which defines the relationship between Intensive Board Monitoring and firm value.

The influence of Intensive Board Monitoring on the value of the firm can be viewed from two different perspectives. The first perspective presumes that Intensive Board Monitoring affects positively on firm's value. This positive effect results from the monitoring role of the board in preventing the managers and controlling shareholders from misusing the firm's resources and harming the minority shareholders. Fama (1980) and Fama \& Jensen (1983) prove that the presence of outside directors in the board tends to reduce the managerial agency problem because they are more willing to confront the firm's CEO's and punish them than the inside members of the board. While the second perspective assumes that firm's valuation is affected negatively by Intensive Board Monitoring. This negative effect results from that the benefits associated with intensive monitoring doesn't exceed the costs that result from hindering the advisory role of the board (Faleye et al., 2011).

In developed markets, the impact of Intensive Board Monitoring on firm's value is proved to be negative (Holmstron, 2005; Faleye et al., 2011). This negativity results from hindering the advisory role of the board, which leads to the dominance of monitoring costs over its benefits. Poor advising could be the outcome of lack of trust on board members by the CEOs to share strategic information with them, which is essential for the board to provide the required advice to the firm. This lack of trust results from that the CEOs feel to be unsupported by the board, as a result, of intensive monitoring. Besides that, intensive monitoring reduces the time devoted to the advisory functions of the board (Adams, 2009). In contrast, Intensive Board Monitoring is proved to be essential for improving firm's value in emerging markets (Byun et al., 2013). The importance of Intensive Board Monitoring generates from three 
main characteristics of emerging markets that differ from those of developed markets. First, the ownership structure is highly concentrated in emerging markets, which raises the agency conflict between the controllers and managers and between the controllers and the minorities (Classens et al., 2000; Faccio \& Lang, 2002). Second, the external governance mechanisms, such as managerial labor market and market for corporate control, are not well developed in emerging markets. This elevates the need for the internal governance mechanisms, such as the ownership structure and the board of directors, to overcome the agency problem. Third, the legal system that protects the investors is weak in emerging markets (La Porta et al., 1999). These characteristics require higher emphasize on the monitoring functions of the board over its advisory functions to overcome the agency problem, which is more severe in emerging markets compared to developed markets. As a result, the impact of Intensive Board Monitoring on firm's value is more likely to be positive in emerging markets because the positive monitoring effect is expected to exceed the negative advising effect. Although the Saudi market is not classified as an emerging one according to the classification of the Morgan Stanley Capital International (MSCI) Emerging Market index, but it has similar characteristics to those of emerging markets (Mansur\& Delgado, 2008; Sedik \& Williams, 2011). Therefore, it's reasonable to propose the following hypothesis:

\section{H: Intensive Board Monitoring affects positively on firm's value}

\section{Data and Variables}

This section is divided into two subsections. The first subsection defines the sources of the data understudy. While the second subsection provides a full definition of all the variables applied in this paper, which include the firm valuation variables, the Intensive Board Monitoring variables, and the control variables.

\subsection{Data Sources}

All the data required regarding the intensity of the board monitoring of Saudi listed firms are provided through Argaam and Tadawul website and through contacting the officials in the Capital Market Authority, CMA, to provide the unpublished data in the websites. The paper covers all the firms listed in the Saudi Stock exchange, except the firms in the banking and insurance sectors, during the period 2008 till 2013. The banking and insurance sectors were excluded, as a result, of their characteristics, which is different from the characteristics of the firms in other sectors. The main difference between these sectors cover the measures of financial statement profitability and liquidity assessment (Soliman, 2013). The coverage of the period 2008 till 2013 is associated with the mandatory Corporate Governance regulations, generated by the board of the Capital Market Authority (CMA), that mandate all Saudi listed firms to apply the audit committee in their boards in the year 2008 and the nomination and remuneration committee in the year 2010. The appliance of these two committees should enhance the monitoring functions of the boards of Saudi listed firms and improve the protection for the investors from illegal acts in the market.

\subsection{Variables}

In this subsection, the definition of the variables understudy are clarified. This subsection is divided into three subsections where the definition of the variables of firm value, Intensive Board Monitoring, and control variables are defined over these three subsections, respectively.

\subsubsection{Variables of Firm's Valuation}

This dissertation applies Tobin's $Q$ as a measure of firm's value. This variable is defined as the ratio of market value of assets to the book value of assets, where the market value of assets is the book value of assets plus the market value of common equity less the sum of the book value of common equity and deferred taxes (if any). An additional measure of firm value is applied based on previous literature; which is Market-to-Book ratio (Byun et al., 2013; Chen \& Zhu, 2006). Market-to-Book ratio is an important measure of firm's value because it reflects the assessment of the investors regarding the future abnormal profits of the firm (Meoli, Paleari, \& Vismara, 2009).

\subsubsection{Variables of Intensive Board Monitoring}

To analyze the intensity of board monitoring among Saudi listed firms, this paper applies three different measures of Intensive Board Monitoring (IBM). The first variable measures the independence of the board as a whole. It defines whether the majority of the outside directors serve in both of the principal board committees of Saudi listed firms, which is the audit and the nomination and remuneration committees (Faleye et al., 2011). These two committees are the principal ones because they are the committees that become effective to apply on all Saudi listed firms and which their roles and responsibilities had been defined precisely by the board of the Capital Market Authority (CMA). The Corporate Governance Regulations shows that the primary function of the two committees is monitoring. Hence, if the majority of outside board members serve in the two committees, then the board is considered as a monitoring 
intensive one. One variable is used to measure the percentage of outside directors who serve in both committees (Ind-comm).

The other two variables measure the independence of the audit and nomination and remuneration board committees (Byun et al., 2013). The first variable measures the percentage of outside directors to total directors in the board committee. If this percentage is high, the independence of the committee increases and its monitoring role dominates its advisory role, which disciplines the controlling shareholders more effectively (Chen \& Zhu, 2006; Byun et al., 2013). Two variables are added to measure the ratio of outside directors in the two committees (Ind-Aud and IndNom\&Rem). While the other variable measures whether the chairman of the board committee is an outside director. If this applies, the board become more independent and its monitoring function strengthen, which reduces the agency conflict between the controlling shareholders and the minorities. Two dummy variables are used that take the value of one if the chairman of any of the two board committees is an outside director, or zero otherwise (Chair-Aud and Chair- Nom\&Rem).

\subsubsection{Other Variables}

We add a list of control variables to the empirical analysis that may affect the valuation of the firm, to avoid spurious correlation. These variables are firm size, leverage, ROA, investment opportunities (Invest-opportune), Free Cash Flows (FCF) and board ownership (Linck, Netter, \& Yang, 2008; Byun et al., 2013; Faleye et al., 2011). Size of the firm is an important control variable because larger firms tend to be more subject to the regulations of corporate governance than small sized firms and, hence, have better valuation. The size of the firm's total assets is the measurement we apply in this dissertation (Faleye et al., 2011). We apply the natural log of total assets in the analysis to control for the variations in total assets among Saudi listed firms. Leverage is defined as the total leverage of the firm divided by its total assets. It's a control mechanism that the firm can apply to control the overinvestment problem because of the obligations and default risk associated with it (Byun et al., 2013). ROA is defined as the ratio of net income to total assets and it's applied to measure the impact of profitability on the valuation of the firm (Byun et al., 2013). Also ROA helps to define whether the accounting measures and the valuation measures of the firm are aligned. Investment opportunities (Invest-opportune) is calculated as the ratio of capital expenditures to sales to capture the growth potentials of the firm (Faleye et al., 2011). Free cash flow is measured as operating income before depreciation minus total income taxes, change in deferred taxes, interest expense, preferred dividends, and dividends on common stock / Total assets. This variable defines the private benefits available to managers (Linck et al. 2008). Board ownership (Board-own) is the proportion of outstanding shares owned by all directors (Faleye et al., 2011). When board members hold a large ownership stake in the firm, their interests are aligned with the shareholder's interest (Raheja, 2005). But in such a case they are not considered as independent, as a result, of their ownership in the firm.

Table (I) in the appendix provides a full description of the variables understudy.

\section{Descriptive Statistics}

This section presents the descriptive statistics of the variables understudy in three subsections. The first subsection defines the means and the second subsection defines the correlations between the variables included in this study. Whereas the third subsection covers the mean values of the board monitoring intensity variables over the years understudy.

\subsection{Mean-Based Analysis}

Table 1 summarizes the means of the firm valuation, Intensive Board Monitoring, and control variables for 119 Saudi listed firms over six years, 714 yearly observations. The table shows that the mean of Tobin's Q is 1.8, while the mean of Market-to-Book ratio is 2.12. For the IBM variables, the mean percentage of outside directors to total directors (Ind. Itotal) is $50.97 \%$, which indicates that the boards of Saudi listed firms are highly independent. The means of the percentage of outside directors to total directors in the audit committee (Ind-Aud) and the nomination and remuneration committee (Ind-Nom \& Rem) are $45.66 \%$ and $47.02 \%$, respectively, and $32.75 \%$ of outside directors serve in both two committees (Ind-Comm). While the mean percentage of firms where the chairman of the audit committee (Chair-Aud) and the nomination and remuneration committee (Chair- Nom \& Rem) is an outside director are $51 \%$ and $42 \%$, respectively. The higher the independence of the audit committee over the nomination and remuneration committee results from mandating Saudi listed firm to apply the audit committee earlier than the nomination and remuneration committee, which led to the higher emphasize and appliance of the Corporate Governance board independence rules on this committee.

Saudi listed firm tend to be large in size. The mean leverage value is $36.2 \%$. While the means of ROA, investment 
opportunities (Invest-Opportune), and FCFs are 6.8\%, 18.1\% and 2.49\%, respectively. The mean number of shares owned by the board members (Board-Own) is $11.16 \%$, which supports the findings of the independence of the boards of Saudi listed firms because the ownership of the board members in these firms is low.

Table 1. Summary statistics for all variables

\begin{tabular}{r|rrrrr} 
Variable & Obs & Mean & Std. Dev. & Min & Max \\
\hline tobinsq & & & & & \\
mbratio & 679 & 1.807066 & 1.147655 & .015 & 8.52 \\
indtotal & 638 & 2.117834 & 1.477957 & .46 & 12.2 \\
indcomm & 594 & .5097168 & .2064379 & 0 & 1 \\
indaud & 583 & .3274884 & .1770293 & 0 & 1 \\
& 583 & .4566243 & .3006655 & 0 & 1 \\
\hline indnomandrem & & & & & \\
chairaud & 558 & .4701904 & .3000146 & 0 & 1 \\
chairnoman m & 583 & .5128645 & .5002637 & 0 & 1 \\
size & 558 & .4229391 & .4944692 & 0 & 1 \\
leverage & 627 & 21.52253 & 1.445866 & 18.66832 & 26.5359 \\
& 678 & .36194 & .2265102 & .002236 & 1.526787 \\
\hline roa & & & & & \\
\hline investoppr & 675 & .0676166 & .1103149 & -.7753938 & .682201 \\
fcf & 636 & .1810945 & .3988544 & .0000155 & 5.336595 \\
boardown & 678 & .0249514 & .0795961 & -.6082465 & .9931724 \\
& 609 & .1115761 & .1775967 & $4.17 e-06$ & .95868
\end{tabular}

Description: This table shows the descriptive statistics of the firm's valuation, IBM and control variables for a sample of 119 Saudi listed firms over six years from 2008 till 2013. The total number of yearly observations understudy is 714. Tobin's Q, is measured as the ratio of market value of assets to the book value of assets, where the market value of assets is the book value of assets plus the market value of common equity less the sum of the book value of common equity and deferred taxes (if any). M-B ratio, is the Market value of common stock / book value of common stock. Ind $\backslash$ Toal, is the percentage of independent board directors to the total number of directors in the firm. Ind-Comm, is the percentage of independent directors who serve in the Audit and the Nomination and Remuneration committees to the total number of directors in the firm. Ind-Aud, is the percentage of independent directors to total number of directors in the Audit committee. Ind-Nom\&Rem, is the percentage of independent directors to total number of directors in the Nomination and Remuneration committee. Chair-Aud, is a binary variable that takes the value of one if the Chairman of the Audit committee is an independent director, or zero otherwise. Chair-Nom\&Rem, is a binary variable that takes the value of one if the Chairman of the Nomination and Remuneration committee is an independent director, or zero otherwise. Size, is the natural log of the firm's total assets. Leverage, is the total leverage of the firm divided by its total assets. ROA, is the ratio of net income to total assets. Invest-Opportune, is the ratio of capital expenditures to sales. FCF, is the operating income before depreciation minus total income taxes, change in deferred taxes, interest expense, preferred dividends, and dividends on common stock / Total assets. Board-Own \%, is the proportion of outstanding shares owned directly by all directors.

\subsection{Correlation-Based Analysis}

Defining the correlations between the variables understudy in Table 2 reveal that the valuation variables, Tobin's $Q$ and $\mathrm{M}-\mathrm{B}$ ratio, are significantly and positively correlated at the $1 \%$ level, with a correlation value of 0.86 . Similar results are obtained among the Intensive Board Monitoring variables, where all of the variables have a positive significant correlation at the $1 \%$ level, which supports the findings of Byun et al. (2013). All of the Intensive Board Monitoring variables are positively correlated with the valuation variables, both Tobin's Q and the M-B ratio. This positive correlation supports the findings of previous research, such as Dahya et al., (2007) and Byun et al., (2013), which reveal a positive impact of board monitoring intensity on the valuation of the firm. All of the control variables, size, leverage, ROA, Invest-Opportune, FCF and Board-own, have a low correlation with all of the independent variables, the IBM variables. 
Table 2. Correlation between variables

\begin{tabular}{|c|c|c|c|c|c|c|c|c|c|c|c|c|}
\hline & tobinsq & mbratio & indcomm & indaud & indnom m & chairau & hairn m & size & leverage & roa & invest re & fcf boardown \\
\hline tobinsq & 1.0000 & & & & & & & & & & & \\
\hline mbratio & 0.8632 & 1.0000 & & & & & & & & & & \\
\hline indcomm & 0.1148 & 0.1078 & 1.0000 & & & & & & & & & \\
\hline indaud & 0.0370 & 0.0315 & 0.6147 & 1.0000 & & & & & & & & \\
\hline indnomandrem & 0.0935 & 0.0699 & 0.7057 & 0.2777 & 1.0000 & & & & & & & \\
\hline chairaud & 0.0828 & 0.0527 & 0.4309 & 0.5899 & 0.1825 & 1.0000 & & & & & & \\
\hline chairnoman m & 0.0370 & 0.0578 & 0.4123 & 0.0398 & 0.5935 & 0.0444 & 1.0000 & & & & & \\
\hline size & 0.0619 & 0.0771 & -0.2084 & -0.1657 & -0.0923 & -0.1771 & -0.0603 & 1.0000 & & & & \\
\hline leverage & -0.2439 & 0.0012 & -0.1051 & -0.1013 & -0.1188 & -0.0890 & -0.0242 & 0.2145 & 1.0000 & & & \\
\hline roa & 0.3269 & 0.1468 & -0.2119 & -0.1346 & -0.1600 & -0.0538 & -0.1341 & 0.2128 & -0.1850 & 1.0000 & & \\
\hline investoppr e & -0.0637 & -0.0834 & 0.0009 & -0.0114 & 0.0368 & -0.0001 & 0.0651 & 0.0972 & 0.0598 & -0.0952 & 1.0000 & \\
\hline$f_{C f}$ & -0.0759 & -0.0626 & -0.1782 & -0.1331 & -0.1486 & -0.1973 & -0.0216 & 0.0092 & 0.0127 & 0.3296 & -0.0416 & 1.0000 \\
\hline boardown & -0.0763 & -0.0458 & -0.1772 & 0.0283 & -0.1691 & -0.0886 & -0.0108 & -0.0573 & -0.0171 & 0.1285 & -0.0324 & 0.2084 \\
\hline
\end{tabular}

Description: This table shows the correlations between the variables understudy for a sample of 119 Saudi listed firms over six years from 2008 till 2013. The total number of yearly observations understudy is 714. Tobin's Q, is measured as the ratio of market value of assets to the book value of assets, where the market value of assets is the book value of assets plus the market value of common equity less the sum of the book value of common equity and deferred taxes (if any). M-B ratio, is the Market value of common stock / book value of common stock. Ind-Comm, is the percentage of independent directors who serve in the Audit and the Nomination and Remuneration committees to the total number of directors in the firm. Ind-Aud, is the percentage of independent directors to total number of directors in the Audit committee. Ind-Nom \& Rem, is the percentage of independent directors to total number of directors in the Nomination and Remuneration committee. Chair-Aud, is a binary variable that takes the value of one if the Chairman of the Audit committee is an independent director, or zero otherwise. Chair-Nom \& Rem, is a binary variable that takes the value of one if the Chairman of the Nomination and Remuneration committee is an independent director, or zero otherwise. Size, is the natural log of the firm's total assets. Leverage, is the total leverage of the firm divided by its total assets. ROA, is the ratio of net income to total assets. Invest-Opportune, is the ratio of capital expenditures to sales. FCF, is the operating income before depreciation minus total income taxes, change in deferred taxes, interest expense, preferred dividends, and dividends on common stock / Total assets. Board-Own $\%$, is the proportion of outstanding shares owned directly by all directors.

\subsection{Time Based Analysis}

A detailed analysis of the Intensive Board Monitoring measures in table (3) reveal that Saudi listed firms are adopting and applying the mandatory rules of the Corporate Governance regulations that is related to the independence of the board over the years understudy from 2008 till 2013. This is proved through the increase in all of the measures of board monitoring intensity over the period understudy. The increase in these measures is inconsistent, where a slight drop occur in the years 2011 and 2012. The reason behind this slight drop could be the variation in the appliance of Saudi listed firms to the audit and the nomination and remuneration committees understudy. Applying the audit committee had become mandatory at the beginning of the year 2008, while the nomination and remuneration committee become mandatory to apply in the year 2010. This variation in adopting these two committees might be the result of the variation in the results among the years.

The percentage of the outside directors who serve in both committees (Ind-Comm) increased from $28.23 \%$ in 2008 to $35.86 \%$ in 2013. Similarly, the percentage of outside directors in the audit committee (Ind-Aud) and the nomination and remuneration committee (Ind-Nom \& Rem) increased from $45.56 \%$ and $39.37 \%$ in 2008 and reached $46.15 \%$ and $51.72 \%$ in 2013 , respectively. The same results are found among the firms where the chairman of the audit and the nomination and remuneration committee is an outside director. The percentage of firms in which the chairman of the audit committee and the chairman of the nomination and remuneration committee is an outside director (Chair-Aud and Chair-Nom \& Rem) increased from $48 \%$ and $32 \%$ in 2008 to $52 \%$ and $53 \%$ in 2013, respectively. In 2010, the percentage of outside directors in the nomination and remuneration committee (Ind-Nom \& Rem) and the percentage of firms in which the chairman of the nomination and remuneration committee is an outside director (Chair-Nom\&Rem) had increased compared to these percentages in the year 2009. The percentage of Ind-Nom \& 
Rem increase from $40.74 \%$ to $49.79 \%$ and the percentage of Chair-Nom \& Rem increase from $33 \%$ to $40 \%$, respectively. The reason behind this rapid increase in the year 2010 results from the resolution Number (1-10-2010) Dated 30/3/1431H corresponding to 16/3/2010G issued by the Board of the Capital Market Authority, that mandates all listed firms to adopt article (15) of the Corporate Governance regulations. This article is related to the set up of the nomination and remuneration committee and the duties and responsibilities of this committee.

These results are higher than the results of Byun et al. (2013). In their study the percentage of outside directors in the audit committee increased from $15.81 \%$ in 2005 and reached $22.96 \%$ in 2009 . While the percentage of firms in which the chairman of the audit committee is an outside director increased from $15.96 \%$ in 2005 to $21.76 \%$ in 2009 . The reason behind the excel of the independence of the board committees among Saudi listed firms over Korean firms is that, unlike Korean firms, most of Saudi listed firms has outside directors in their board committees. Besides that, the period understudy in this paper is more recent than the period in Byun's study, 2008 till 2013 vs. 2005 till 2009 , respectively. The more the recent the period understudy, the more the firm's management and owners become aware of the importance of complying the Corporate Governance regulations and how adopting these regulations can improve the valuation and performance of the firm.

Table 3. Average percentages of IBM measures during each year

\begin{tabular}{lcccccc}
\hline Year & Ind/Total & Ind-Comm & Ind-Aud & $\begin{array}{c}\text { Ind-Nom \& } \\
\text { Rem }\end{array}$ & $\begin{array}{c}\text { Chair-Aud } \\
\text { Chair-Nom } \\
\text { \&Rem }\end{array}$ \\
\hline $\mathbf{2 0 0 8}$ & $54.90 \%$ & $28.23 \%$ & $45.56 \%$ & $39.37 \%$ & 0.48 & 0.32 \\
\hline $\mathbf{2 0 0 9}$ & $54.40 \%$ & $28.74 \%$ & $46.51 \%$ & $40.74 \%$ & 0.52 & 0.33 \\
\hline $\mathbf{2 0 1 0}$ & $51.35 \%$ & $33.96 \%$ & $46.97 \%$ & $49.79 \%$ & 0.51 & 0.40 \\
\hline $\mathbf{2 0 1 1}$ & $49.32 \%$ & $33.81 \%$ & $46.31 \%$ & $47.72 \%$ & 0.51 & 0.39 \\
\hline $\mathbf{2 0 1 2}$ & $48.34 \%$ & $33.37 \%$ & $42.85 \%$ & $47.58 \%$ & 0.52 & 0.48 \\
\hline $\mathbf{2 0 1 3}$ & $49.64 \%$ & $35.86 \%$ & $46.15 \%$ & $51.72 \%$ & 0.52 & 0.53 \\
\hline Total & $50.97 \%$ & $32.75 \%$ & $45.66 \%$ & $47.02 \%$ & 0.51 & 0.42 \\
\hline
\end{tabular}

Description: The table shows the means of the variables of Intensive Board Monitoring in each year understudy. The analysis is applied on a sample of 119 Saudi listed firms over six years from 2008 till 2013. The total number of yearly observations understudy is 714 . Ind $\backslash$ Toal, is the percentage of independent board directors to the total number of directors in the firm. Ind-Comm, is the percentage of independent directors who serve in the Audit and the Nomination and Remuneration committees to the total number of directors in the firm. Ind-Aud, is the percentage of independent directors to total number of directors in the Audit committee. Ind-Nom\&Rem, is the percentage of independent directors to total number of directors in the Nomination and Remuneration committee. Chair-Aud, is a binary variable that takes the value of one if the Chairman of the Audit committee is an independent director, or zero otherwise. Chair-Nom\&Rem, is a binary variable that takes the value of one if the Chairman of the Nomination and Remuneration committee is an independent director, or zero otherwise.

\section{Empirical Analysis}

This section is devoted to the empirical analysis and it's divided into two subsections. In the first subsection we analyze the impact of Intensive Board Monitoring on the value of the firm through applying the Ordinary Least Square (OLS) approach. Whereas in the second subsection the endogenity problem is examined through applying the Two Stage Least Square (2SLS) approach.

\subsection{The Ordinary Least Square-Based Regression}

To analyze the impact of board monitoring intensity on the valuation of the firm we apply the following regression analysis through applying the OLS approach:

Firm value $=b_{0}+b_{1}$ IBMi $_{i t}+b_{2}$ Size $_{i t}+b_{3}$ Leverage $_{i t}+b_{4}$ ROA $_{i t}+b_{5}$ Invest- opportune $_{i t}+b_{6} F_{C F} F_{i t}+b_{7}$ Board-Own $_{\text {it }}+e_{i t}$

In the above regression, firm value is measured by Tobin's $Q$ and Market-to-Book ratio. While IBMi defines the board monitoring intensity variables applied in this study (Ind-Comm, Ind-Aud, Ind-Nom \& Rem, Chair-Aud and Chair-Nom \& Rem). Industry and year dummy variables are added to the equation to control for the specific sector and year effects. The definitions of all the variables is listed in the table in the appendix.

Sections (A) and (B) of table (4) represent the results of analyzing the impact of Intensive Board Monitoring on firm value through applying the Ordinary Least Square approach (OLS). Similar results are obtained when Tobin's Q and M-B ratio are applied as the dependent variables, respectively. The results support to some extent our first hypothesis, 
which indicates a positive impact of Intensive Board Monitoring on firm value. The results reveal that all of the Intensive Board Monitoring variables has a positive impact on the valuation of the firm, but not all of them are significant. The variables that are related to the independence of both committees and the independence of the Audit committee in models 1, 2 and 4 (Ind-Comm, Ind-Aud, and Chair-Aud) are significant at the $1 \%$ level and 5\% level of significance, respectively. While the variables that are related to the independence of the Nomination and Remuneration committee in models 3 and 5 are positive but not significant (Ind-Nom \& Rem and Chair-Nom \& Rem). The reason behind such results might be that article (15) that mandates all listed firms in the Saudi market to set up a Nomination and Remuneration committee become effective only in 2010 according to resolution Number (1-10-2010) Dated $30 / 3 / 1431 \mathrm{H}$ corresponding to $16 / 3 / 2010 \mathrm{G}$. This might affect the results of the analysis because the adaptation was not effective from the beginning of the study period, 2008-2013. Another reason behind the above results might be the endogeneity problem, that will be discussed in the following subsection, between board monitoring intensity and firm value. The size of the firm and the ROA both have a positive and significant impact on the valuation of the firm, measured by Tobin's Q and M-B ratio. This indicates that larger firms with higher total assets and firms with high return on their assets tend to have better valuation than other firms. Besides that, the positive and significant impact of ROA on firm value reveal that the accounting measures of performance support the performance measured by market value, both Tobin's Q and M-B ratio, among Saudi listed firms. When Tobin's Q is applied as the firm valuation variable, both of leverage and FCF variables tend to have a negative significant impact at the $1 \%$. This indicates that high amounts of leverage tend to destroy the value of the firm, either because the leverage is too high or because there is no tax shield to reduce the cost of leverage. These results reveal that Saudi listed firms that finance their needs of capital with equity are performing better than the firms that finances their needs with leverage. Similarly, the negative and significant impact of the FCFs on firm value indicates a misuse of the firm's FCFs by the firm's management, which support the entrenchment hypothesis (Linck et al., 2008). The negative and significant impact of FCF persist when M-B ratio is applied as the valuation variable, while the negative impact of leverage become insignificant. Investment opportunities (Invest-Opportune) and board ownership (Board-Own\%) both have a negative but insignificant impact on Tobin's Q and M-B ratio. The negative impact of Investment opportunities supports the findings of the negative impact of the FCFs and leverage on firm value. These findings all support the view that the firm's resources, including its FCFs and leverage, are not well used by the firm's managers, which again support the entrenchment hypothesis. The negative impact of the ownership of the board on firm value, although it's not significant, but it gives an indication that board members who are not independent tend to generate private benefits of control and affect negatively on firm value. The joint effect of year and sector is significant at the $1 \%$ level. 
Table 4. The impact of IBM on firm value (OLS)

\begin{tabular}{|c|c|c|c|c|c|}
\hline & & & $\begin{array}{l}\text { Section (A): } \\
\text { Tobin's Q }\end{array}$ & & \\
\hline & Model (1) & Model (2) & Model (3) & Model (4) & Model (5) \\
\hline (Constant) & $1.155(0.249)$ & $1.538(0.125)$ & $1.944(0.052)$ & $1.364(0.173)$ & $2.113(0.035)$ \\
\hline Ind-Comm & $2.657(0.008)^{* * *}$ & & & & \\
\hline Ind-Aud & & $1.940(0.053)^{* *}$ & & & \\
\hline Ind-Nom \& Rem & & & $1.275(0.203)$ & & \\
\hline Chair-Aud & & & & $2.389(0.017)^{* *}$ & \\
\hline Chair- Nom \& Rem & & & & & $0.880(0.380)$ \\
\hline Size & $2.346(0.019) * *$ & $2.140(0.033)^{* *}$ & $1.694(0.091)^{*}$ & $2.358(0.019)^{* *}$ & $1.658(0.098)^{*}$ \\
\hline leverage & $-4.546(0.000)^{* * *}$ & $-4.590(0.000)^{* * *}$ & $-4.471(0.000) * * *$ & $-4.659(0.000) * * *$ & $-4.518(0.000)^{* * *}$ \\
\hline ROA & $7.042(0.000) * * *$ & $6.830(0.000) * * *$ & $6.529(0.000)^{* * * *}$ & $6.479(0.000)^{* * *}$ & $6.471(0.000)^{* * *}$ \\
\hline Invest-Opportune & $-0.281(0.779)$ & $-0.250(0.799)$ & $-0.218(0.828)$ & $-0.359(0.720)$ & $-0.239(0.811)$ \\
\hline FCF & $-4.474(0.000)^{* * *}$ & $-4.370(0.000)^{* * *}$ & $-4.421(0.000) * * *$ & $-4.172(0.000) * * *$ & $-4.479(0.000) * *$ \\
\hline board-own & $-1.214(0.225)$ & $-1.520(0.128)$ & $-1.129(0.260)$ & $-1.313(0.190)$ & $-1.306(0.192)$ \\
\hline Industry Effect & Yes & Yes & Yes & Yes & Yes \\
\hline Year Effect & Yes & Yes & Yes & Yes & Yes \\
\hline Adjusted R square & 0.317 & .0 .340 & 0.300 & 0.315 & 0.300 \\
\hline
\end{tabular}

\begin{tabular}{|c|c|c|c|c|c|}
\hline & \multicolumn{5}{|c|}{$\begin{array}{l}\text { Section (B): } \\
\text { M-B ratio }\end{array}$} \\
\hline & Model (1) & Model (2) & Model (3) & Model (4) & Model (5) \\
\hline (Constant) & $0.544(0.587)$ & $0.863(0.388)$ & $1.332(0.184)$ & $0.861(0.390)$ & $1.433(0.153)$ \\
\hline Ind-Comm & $2.680(0.008)^{* * *}$ & & & & \\
\hline Ind-Aud & & $2.167(0.031)^{* *}$ & & & \\
\hline $\begin{array}{l}\text { Ind-Nom \& } \\
\text { Rem }\end{array}$ & & & $0.785(0.433)$ & & \\
\hline Chair-Aud & & & & $2.161(0.031)^{* *}$ & \\
\hline $\begin{array}{l}\text { Chair- Nom \& } \\
\text { Rem }\end{array}$ & & & & & $0.631(0.528)$ \\
\hline Size & $2.359(0.019) * *$ & $2.193(0.029) * *$ & $1.783(0.075)^{*}$ & $2.273(0.023)^{* *}$ & $1.760(0.079)^{*}$ \\
\hline leverage $\%$ & $-0.127(0.899)$ & $-0.116(0.908)$ & $-0.063(0.950)$ & $-0.120(0.905)$ & $-0.094(0.925)$ \\
\hline ROA & $3.143(0.002)^{* * *}$ & $2.910(0.004)^{* * *}$ & $2.613(0.009) * * *$ & $2.593(0.010)^{* * *}$ & $2.591(0.010)^{* * *}$ \\
\hline $\begin{array}{l}\text { Invest- } \\
\text { Opportune }\end{array}$ & $-1.120(0.263)$ & $-1.095(0.274)$ & $-1.139(0.255)$ & $-1.199(0.231)$ & $-1.159(0.247)$ \\
\hline FCF & $-2.608(0.009)^{* * *}$ & $-2.588(0.010) * * *$ & $-2.774(0.006)^{* * *}$ & $-2.453(0.015)^{* *}$ & $-2.850(0.005) * * *$ \\
\hline board-own \% & $-0.402(0.688)$ & $-0.730(0.466)$ & $-0.395(0.693)$ & $-0.509(0.611)$ & $-0.504(0.615)$ \\
\hline Industry Effect & Yes & Yes & Yes & Yes & Yes \\
\hline Year Effect & Yes & Yes & Yes & Yes & Yes \\
\hline $\begin{array}{l}\text { Adjusted R } \\
\text { square }\end{array}$ & 0.227 & .0 .223 & 0.214 & 0.223 & 0.214 \\
\hline
\end{tabular}


Description: This table shows the regression analysis of firm value on Intensive Board Monitoring variables and the control variables for a sample of 119 Saudi listed firms over six years from 2008 till 2013. The total number of yearly observations understudy is 714 . Tobin's $Q$, is measured as the ratio of market value of assets to the book value of assets, where the market value of assets is the book value of assets plus the market value of common equity less the sum of the book value of common equity and deferred taxes (if any). M-B ratio, is the Market value of common stock / book value of common stock. Ind-Comm, is the percentage of independent directors who serve in the Audit and the Nomination and Remuneration committees to the total number of directors in the firm. Ind-Aud, is the percentage of independent directors to total number of directors in the Audit committee. Ind-Nom \& Rem, is the percentage of independent directors to total number of directors in the Nomination and Remuneration committee. Chair-Aud, is a binary variable that takes the value of one if the Chairman of the Audit committee is an independent director, or zero otherwise. Chair-Nom\&Rem, is a binary variable that takes the value of one if the Chairman of the Nomination and Remuneration committee is an independent director, or zero otherwise. Size, is the natural log of the firm's total assets. Leverage, is the total leverage of the firm divided by its total assets. ROA, is the ratio of net income to total assets. Invest-Opportune, is the ratio of capital expenditures to sales. FCF, is the operating income before depreciation minus total income taxes, change in deferred taxes, interest expense, preferred dividends, and dividends on common stock / Total assets. Board-Own\%, is the proportion of outstanding shares owned directly by all directors. Year and Industry Effect are dummy variables. The numbers in the table represents the t-statistics values and the numbers in brackets represent the significance level. ***,**, and * indicate a significance level of $1 \%, 5 \%$, and $10 \%$, respectively.

\subsection{Endogeneity Problem}

In this kind of relationship between Intensive Board Monitoring and firm value the endogeneity issue should be considered. As Intensive Board Monitoring could affect the valuation of the firm, firm value can determine the intensity of board monitoring as well. This endogeneity problem could be the reason behind the insignificance of the results in the OLS regression. The negative significant impact, at the 1\% level in Table 4, of the Free Cash Flows (FCF) on firm value supports this endogeneity effect (Bhagat \& Black, 1999). The FCFs in Saudi listed firms are not well used by the managers of these firms, which requires higher independence by the board to control the misuses of those managers. In such a case, the misuses of the FCFs and the poor valuation of the firm determine the board monitoring intensity. To overcome this endogeneity problem we should add instrumental variables to the analysis and apply a simultaneous equation framework.

\subsubsection{Instrumental Variables Based Analysis}

When we analyze the endogenous nature of the Intensive Board Monitoring variables, the results of the analysis show that all of the Intensive Board Monitoring variables are endogenous, which force us to measure this problem through a simultaneous equation framework (Linck et al., 2008; Pana, 2010). In the simultaneous equation framework, instrumental variables are added. To be valid, the instrumental variables must be exogenous. This means that it should be highly correlated with the independent variable (IBM) and can predict the dependent variable (Firm value) indirectly or through the independent variable (Black \& Kim, 2011). We apply two instrumental variables, one is the lag value of the Intensive Board Monitoring variables and the second one is the Indltotal variable that measures the percentage of outside directors to the total number of directors in the board. The second variable is chosen because it can provide an overview about the overall independence of the boards of Saudi listed firms.

Table 5 reveal that all of the Intensive Board Monitoring variables are affected positively and significantly at the 1\% level by the two instrumental variables. This indicates that these two variables are good instrumental variables for the simultaneous equation framework. 
Table 5. The impact of instrumental variables on IBM

\begin{tabular}{|c|c|c|c|c|c|}
\hline & $\begin{array}{l}\text { Model (1) } \\
\text { Ind-Comm }\end{array}$ & $\begin{array}{l}\text { Model (2) } \\
\text { Ind-Aud }\end{array}$ & $\begin{array}{c}\text { Model (3) } \\
\text { Ind-Nom\&Rem }\end{array}$ & $\begin{array}{l}\text { Model (4) } \\
\text { Chair-aud }\end{array}$ & $\begin{array}{c}\text { Model (5) } \\
\text { Chair- } \\
\text { Nom\& } \& \text { em }\end{array}$ \\
\hline (Constant) & $0.090(0.926)$ & $2.370(0.018)$ & $-0.470(0.936)$ & $3.030(0.003)$ & $-1.43(0.154)$ \\
\hline LagInd-Comm & $13.44(0.000)^{* * *}$ & & & & \\
\hline LagInd-Aud & & $9.020(0.000) * * *$ & & & \\
\hline $\begin{array}{l}\text { Lag- } \\
\text { IndNom\&Rem }\end{array}$ & & & $3.25(0.001)^{* * *}$ & & \\
\hline $\begin{array}{l}\text { Lag-Chair- } \\
\text { Aud }\end{array}$ & & & & $17.27(0.000) * * *$ & \\
\hline $\begin{array}{l}\text { Lag-Chair- } \\
\text { Nom\&Rem }\end{array}$ & & & & & $16.00(0.000)^{* * *}$ \\
\hline Ind \total & $10.24(0.000)^{* * *}$ & $5.240(0.000) * * *$ & $9.530(0.000)^{* * *}$ & $3.10(0.002)^{* * *}$ & $5.09(0.000)^{* * *}$ \\
\hline Size & $-0.200(0.841)$ & $-1.260(0.209)$ & $1.530(0.128)$ & $-3.299(0.001)^{* * *}$ & $1.45(0.149)$ \\
\hline leverage & $-1.680(0.094)^{*}$ & $-0.630(0.530)$ & $-0.690(0.490)$ & $-0.340(0.736)$ & $0.62(0.533)$ \\
\hline ROA & $-1.990(0.047)^{* *}$ & $-0.200(0.844)$ & $-1.750(0.082)^{*}$ & $2.840(0.005)$ & $-2.64(0.009)^{* * *}$ \\
\hline $\begin{array}{l}\text { Invest- } \\
\text { Opportune }\end{array}$ & $0.830(0.405)$ & $-0.400(0.691)$ & $1.170(0.245)$ & $0.81(0.417)$ & $1.28(0.201)$ \\
\hline FCF & $1.740(0.083)$ & $-0.790(0.431)$ & $0.550(0.582)$ & $-2.52(0.012)^{* *}$ & $1.53(0.127)$ \\
\hline board-own & $-1.410(0.159)$ & $1.860(0.063)$ & $-2.920(0.004) * * *$ & $-0.99(0.324)$ & $0.44(0.662)$ \\
\hline Year Effect & Yes & Yes & Yes & Yes & Yes \\
\hline Sector Effect & Yes & Yes & Yes & Yes & Yes \\
\hline $\begin{array}{l}\text { Adjusted R } \\
\text { square }\end{array}$ & 0.620 & 0.337 & 0.312 & 0.073 & 0.154 \\
\hline
\end{tabular}

Description: This table shows the regression analysis of the instrument variables on Intensive Board Monitoring variables and the control variables for a sample of 119 Saudi listed firms over six years from 2008 till 2013. The total number of yearly observations understudy is 714. Ind-Comm, is the percentage of independent directors who serve in the Audit and the Nomination and Remuneration committees to the total number of directors in the firm. Ind-Aud, is the percentage of independent directors to total number of directors in the Audit committee. Ind-Nom\&Rem, is the percentage of independent directors to total number of directors in the Nomination and Remuneration committee. Chair-Aud, is a binary variable that takes the value of one if the Chairman of the Audit committee is an independent director, or zero otherwise. Chair-Nom\&Rem, is a binary variable that takes the value of one if the Chairman of the Nomination and Remuneration committee is an independent director, or zero otherwise. Indltotal, is the percentage of independent directors to the total number of directors in the board. Lag Ind-Comm, Lag Ind-Aud, Lag Ind-Nom\&Rem, Lag Chair-Aud and Lag Chair-Nom\&Rem are the lag values of the Ind-Comm, Ind-Aud, Ind-Nom\&Rem, Chair-Aud and Chair-Nom\&Rem variables, respectively. Size, is the natural log of the firm's total assets. Leverage, is the total leverage of the firm divided by its total assets. ROA, is the ratio of net income to total assets. Invest-Opportune, is the ratio of capital expenditures to sales. FCF, is the operating income before depreciation minus total income taxes, change in deferred taxes, interest expense, preferred dividends, and dividends on common stock /Total assets. Board-Own\%, is the proportion of outstanding shares owned directly by all directors. Year and Industry Effect are dummy variables. The numbers in the table represents the t-statistics values and the numbers in brackets represent the significance level. ${ }^{* *}, * *$, and * indicate a significance level of $1 \%, 5 \%$, and $10 \%$, respectively. 


\subsubsection{The Two- Stage Least Square-Based Analysis}

In Table 6 the methodology we apply for the simultaneous equation framework is the Two- Stage Least Square approach (2SLS) for both of the dependent variables, Tobin's Q and M-B ratio. The results in the table in both sections show that the 2SLS framework provide better estimation for the dependent variables than the OLS method. The variables that are related to the independence of the Nomination and Remuneration committee in models 3 and 5 (Ind-Nom \& Rem and Chair-Nom \& Rem) that were insignificant in the OLS estimation become significant under the 2SLS framework at the $1 \%$ and $5 \%$ level, respectively. While the variables that are related to the independence of both committees and the independence of the Audit committee in models 1, 2 and 4 (Ind-Comm, Ind-Aud, and Chair-Aud) become more significant under the 2SLS estimation.

Table 6. The impact of IBM on firm value (2SLS)

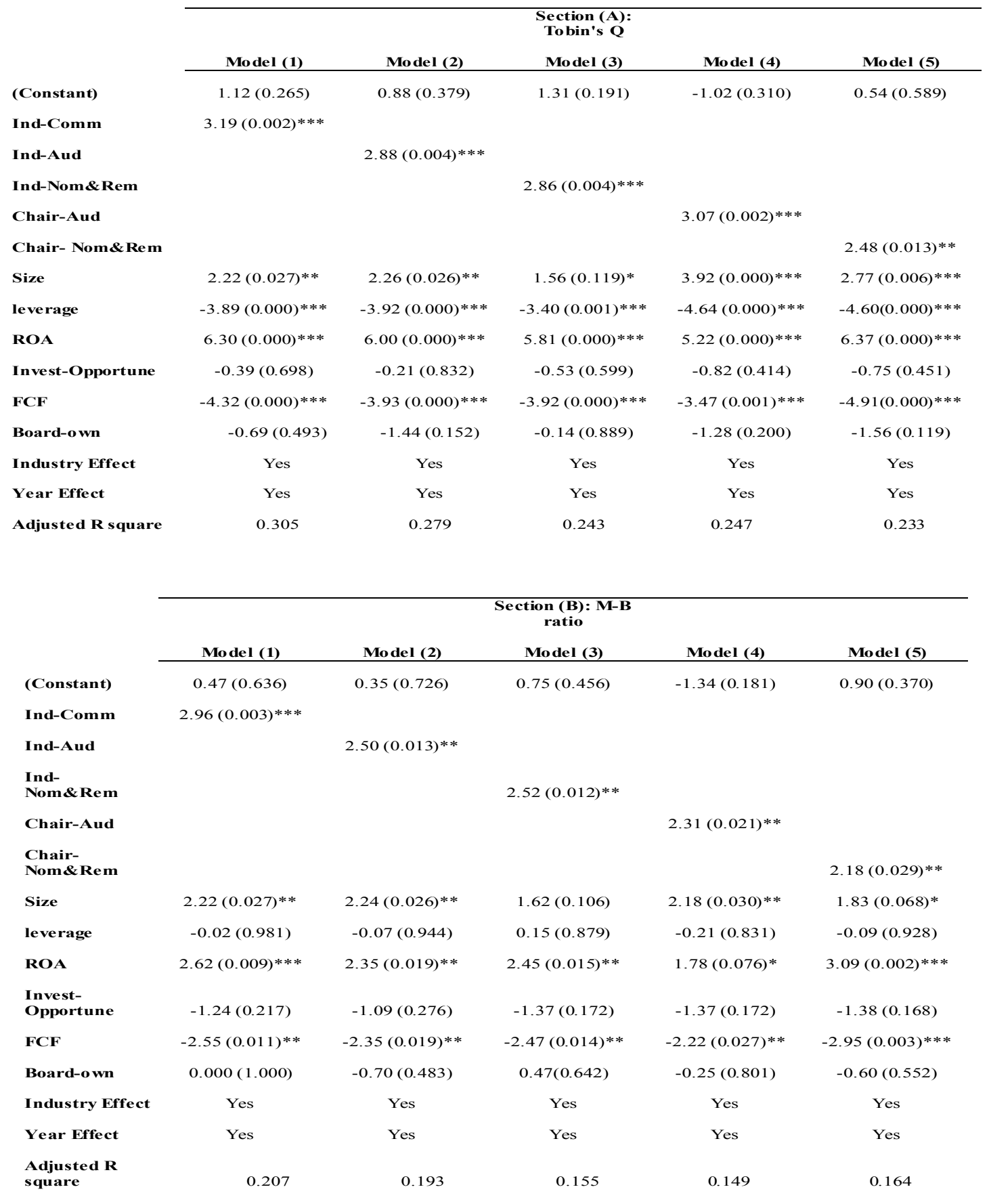


Description: This table shows the regression analysis of the simultaneous equation framework for a sample of 119 Saudi listed firms over six years from 2008 till 2013. The total number of yearly observations understudy is 714 . Tobin's Q, is measured as the ratio of market value of assets to the book value of assets, where the market value of assets is the book value of assets plus the market value of common equity less the sum of the book value of common equity and deferred taxes (if any). M-B ratio, is the Market value of common stock / book value of common stock. Ind-Comm, is the percentage of independent directors who serve in the Audit and the Nomination and Remuneration committees to the total number of directors in the firm. Ind-Aud, is the percentage of independent directors to total number of directors in the Audit committee. Ind-Nom\&Rem, is the percentage of independent directors to total number of directors in the Nomination and Remuneration committee. Chair-Aud, is a binary variable that takes the value of one if the Chairman of the Audit committee is an independent director, or zero otherwise. Chair-Nom\&Rem, is a binary variable that takes the value of one if the Chairman of the Nomination and Remuneration committee is an independent director, or zero otherwise. Size, is the natural log the firm's total assets. Leverage, is the total leverage of the firm divided by its total assets. ROA, is the ratio of net income to total assets. Invest-Opportune, is the ratio of capital expenditures to sales. FCF, is the operating income before depreciation minus total income taxes, change in deferred taxes, interest expense, preferred dividends, and dividends on common stock / Total assets. Board-Own\%, is the proportion of outstanding shares owned directly by all directors. Year and Industry Effect are dummy variables. The numbers in the table represents the t-statistics values and the numbers in brackets represent the significance level. $* * *, * *$, and $*$ indicate a significance level of $1 \%, 5 \%$, and $10 \%$, respectively.

\subsubsection{Hausman and Over-identification Analysis}

To reassure the findings of the 2SLS approach, we form a Hausman test to compare between the 2SLS and OLS methods for both of the dependent variables, Tobin's Q and M-B ratio. The results of the Hausman test, in table (7) in both sections, reveal that the 2SLS estimation is better than the OLS method in estimating Tobin's Q and M-B ratio. When the Ind-comm, Ind-Aud, Ind- Nom \& Rem and Chair-Aud variables are applied, the Hausman statistics give large and significant difference between the two methods. While the difference is small between the two methods when the Chair-Nom \& Rem variable is applied as the independent variable. These results are supported by the findings of the over-identification test (Sargan statistic) in Table 7. This test reveal that the problem of endogeneity caused by the IBM variables is resolved at the $10 \%$ level when the 2SLS approach is applied, as the p-values are larger than 0.1. Supporting the Hausman test, the p-values of the Ind-Comm, Ind-Aud, Ind-Nom \& Rem and Chair-Aud variables are more significant than the P-vale of the Chair-Nom \& Rem variable, which is very high (0.999). The low significance of the Chair-Nom \& Rem variable can be attributed to the independence of the board members (Bahgat \& Black, 1999). Some of the board members might not be truly independent from the firm they serve in its board. They might have some relationship with the firm's owners or its managers. If those board members become chairman of a board committee, this will affect the independence of the board committee and the board as a whole. The impact of the independence of the board members is more prevailed over the Chair-Nom \& Rem variable than the Chair-Aud variable, because the nomination and remuneration committee become mandatory to apply by Saudi listed firms in 2010, which is two years after mandating Saudi listed firm to apply the audit committee, in 2008. This late adaptation of the nomination and remuneration committee can affect the independence of its members, specifically when they hold the position of the chairman of the committee. The members who were considered as independent before mandating Saudi listed firms to apply this committee in 2010 might not be truly independent, which could be the cause of the low significance of the Chair-Nom \& Rem variable. This is supported by the findings in the descriptive statistics, which reveal that the mean value of the firms in which the chairman of the board committee is an outside director is higher among the audit committee compared to the nomination and remuneration committee over the years understudy. The mean value of the firms where the chairman of its audit committee is an outside director (chair-Aud) is $48 \%$ in 2008 compared to $51 \%$ in 2013 . While the mean value of the firms in which the chairman of its nomination and remuneration committee is an outside director (chair-Nom \& Rem) is $32 \%$ in 2008 compared to $42 \%$ in 2013. 
Table 7. Hausman and over-identification test (Sargan statistic)

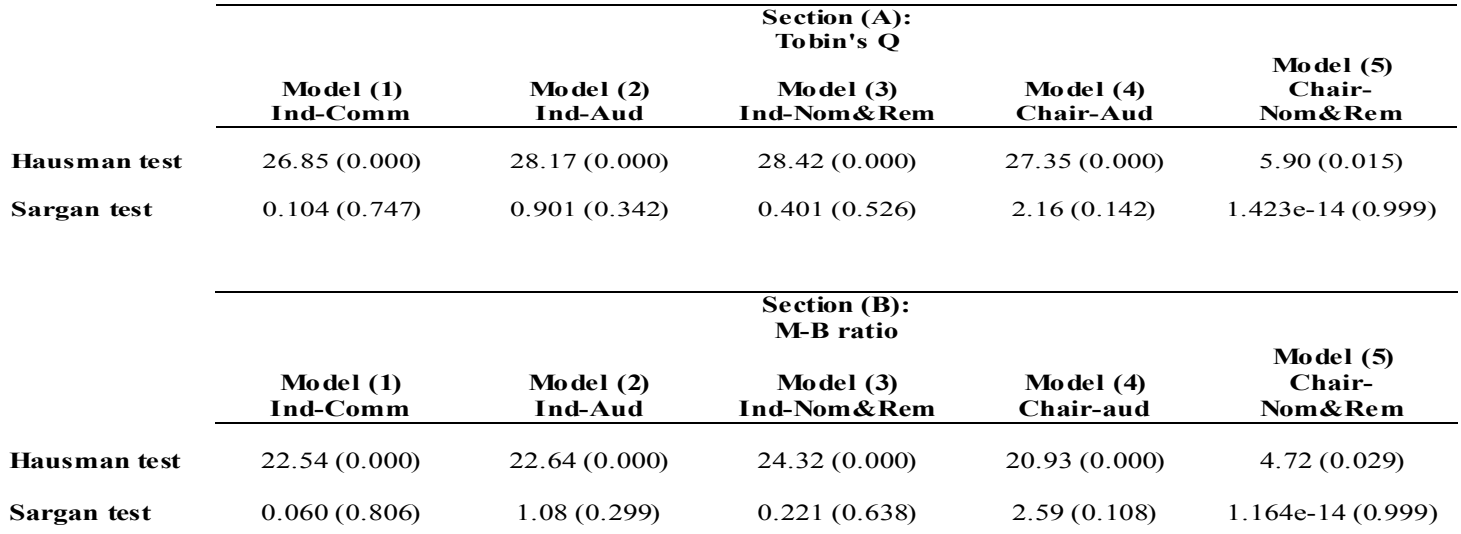

Description: This table shows the analysis of the hausman test and Sargan test for a sample of 119 Saudi listed firms over six years from 2008 till 2013. The total number of yearly observations understudy is 714 . Ind-Comm, is the percentage of independent directors who serve in the Audit and the Nomination and Remuneration committees to the total number of directors in the firm. Ind-Aud, is the percentage of independent directors to total number of directors in the Audit committee. Ind-Nom\&Rem, is the percentage of independent directors to total number of directors in the Nomination and Remuneration committee. Chair-Aud, is a binary variable that takes the value of one if the Chairman of the Audit committee is an independent director, or zero otherwise. Chair-Nom\&Rem, is a binary variable that takes the value of one if the Chairman of the Nomination and Remuneration committee is an independent director, or zero otherwise.

\section{Conclusion}

This paper provides a detailed analysis of the relationship between Intensive Board Monitoring and firm value among Saudi listed firms. The results of the analysis are consistent with our hypothesis. The results reveal that intensive monitoring by the board has a positive impact on the value of Saudi listed firms, measured by Tobin's Q and M-B ratio. This positive impact become more significant when we apply the 2SLS approach compared to the OLS approach, which prove the endogenous nature of the Intensive Board Monitoring variable. These findings prove the effectiveness of the monitoring functions of the boards of Saudi listed firms over their advisory functions, and that the outside board members are more effective monitors than the inside members of the board. The outside board members provide the required monitoring over the firm's managers and controlling shareholders and prevent them from misusing the firm's resources.

All the above findings should provide a better understanding for the officials in the Saudi market regarding the role of board monitoring in improving the firm value. These findings should help the regulators to assess the kind of improvements that Intensive Board Monitoring can provide to the valuation of Saudi listed firms. Also it should increase the confidence of the investors in the Saudi stock market because of the positive role the boards of listed firms play in improving the valuation of these firms.

It's advised for coming research to analyze deeply the role of the new corporate law in enhancing and improving the monitoring functions of the board and its role in preventing the misuses of the controlling shareholders. The Saudi Arabia's council of ministers had approved in the 9th of November, 2015 the new company's law $1437 \mathrm{H} / 2015 \mathrm{G}$. This new law is applied in May, 2016 to overcome the drawbacks of previous corporate law. One of the rules of the new law prohibits any executive member in the firm to combine between his executive position and the position of the chairman of the board of directors. Such rule and other rules in the new law should improve the effectiveness of the board of directors, and more specifically its monitoring functions. This kind of analysis is considered an extension to our work in this paper and can provide a better outlook to the role of the board of directors under the new corporate law.

\section{Acknowledgements}

This is a research project that was supported by a grant from the Research Center for the Humanities, Deanship of Scientific Research at King Saud University.

\section{References}

Adams, R. B. (2009). Asking Directors about Their Dual Roles (Finance Working Paper No. 243). Finance and Corporate Governance Conference 2010 Paper. Retrieved from http://ssrn.com/abstract=1362339 
Adams, R. B., \& Ferreira, D. (2007). A Theory of Friendly Boards. The Journal of Finance, 62(1), 217-250.

Alagaratnam, S. T. (2002). The Impact of Outside Directors and the Board on the Financial Performance of Large Federally-Chartered Savings and Loans Banks in the United States of America (Doctoral dissertation). Retrieved from ProQuest Dissertations Publishing. (NQ82766).

Amer, M., Ragab, A., \& Shehata, S. (2014). Audit Committee Characteristics and Firm Performance: Evidence from Egyptian Listed Companies. Paper presented at the 6th Annual American Business Research Conference on Sheraton LaGuardia East Hotel, New York, USA.

Bhagat, S., \& Black, B. (1999). The Uncertain Relationship between Board Composition and Firm Performance. Business Lawyer, 54, 921-963.

Black, B., \& Kim, W. (2011). The Effect of Board Structure on Firm Value: A Multiple Identification Strategies Approach Using Korean Data. Journal of Financial Economics, 104(1), 203-226.

Bortolotti, B., \& Faccio, M. (2009). Government Control of Privatized Firms. The Review of Financial Studies, 22(8), 2907-2939.

Byun, H., Lee, J., \& Park, K. (2013). Ownership Structure, Intensive Board Monitoring, and Firm Value: Evidence from Korea. Asia-Pacific Journal of Financial Studies, 42(2), 191-227.

Capital Market Authority. (2006, November). Corporate Governance Regulations. Retrieved from http://cma.org.sa/En/Documents/CORPORATE\%20GOVERNANCE.pdf

Chan, K. C., \& Li, J. (2008), Audit Committee and Firm Value: Evidence on Outside Top Executives as Expert Independent Directors. Corporate Governance: An International Review, 16(1), 16-31.

Chen, C., \& Zhu, S. (2006). Ultimate Shareholder, Government Control, and Firm Performance in China (Working Paper No. 10.2139). The Third International Symposium on Corporate Governance Papers.

Claessens, S., Djankov, S., \& Lang, L. (2000). The Separation of Ownership and Control in East Asian Corporations. Journal of Financial Economics, 58, 81-112.

Dahya, J., \& McConnell, J. J. (2007). Board Composition, Corporate Performance, and the Cadbury Committee Recommendation. Journal of Financial and Quantitative Analysis, 42(3), 535-564.

Dahya, J., Dimitrov, O., \& Mcconnell, J. J. (2007). Dominant Shareholders, Corporate Boards, and Corporate Value: A Cross-Country Analysis. Journal of Financial Economics, 87(1), 73-100.

Davis, J. H. (1991). Board Leadership Roles and Shareholder Returns: An Examination of Agency Theory (Doctoral dissertation). The University of Iowa.

Demb, A., \& Neubauer, F. (1992). The Corporate Board: Confronting the Paradoxes. Long Range Planning, 25(3), 9-20.

Faccio, M., \& Lang, L. H. P. (2002). The Ultimate Ownership of Western European Corporations. Journal of Financial Economics, 65(3), 365-395.

Faleye, O., Hoitash, R., \& Hoitash, U. (2011). The Costs of Intense Board Monitoring. Journal of Financial Economics, 101, 160-181.

Fama, E. (1980). Agency Problems and the Theory of the Firm. The Journal of Political Economy, 88(2), 288-307.

Fama, E. F., \& Jensen, M. C. (1983). Separation of Ownership and Control. Journal of Law and Economics, 26(2), 301-325.

Hillman, A. J., \& Dalziel, T. (2003). Boards of Directors and Firm Performance: Integrating Agency and Resource Dependence Perspectives. Academy of Management Review, 28(3), 383-396.

Jensen, M. C. (1993). The Modern Industrial Revolution, Exit, and the Failure of Internal Control Systems. The Journal of Finance, 48, 831-880.

Jensen, M., \& Meckling, W. (1976) Theory of the Firm: Managerial Behavior, Agency Costs and Ownership Structure. Journal of Financial Economics, 3(4), 305-360.

La Porta, R., Lopez-de-Silanes, F., \& Shleifer, A. (1999). Corporate Ownership around the World. The Journal of Finance, 54(2), 471-517.

Lahlou, I., \& Navatte, P. (2013). Advisory Directors' presence on the Board: Does it Matter?. Paper presented at the 32th International Conference of the French Finance Association ( AFFI ), France.

Linck, J., Netter, J., \& Yang, T. (2008). The Determinants of Board Structure. Journal of Financial Economics, 87(2), 308-328. 
Maassen, G. (1999). An International Comparison of Corporate Governance Models (Doctoral Dissertation). Retrieved from www.developmentwork.org

Mansur, A., \& Delgado, F. (2008). Stock Market Developments in the Countries of the Gulf Cooperation Council. UK: Palgrave Macmillan.

McMullen, D. A. (1996). Audit Committee Performance: An Investigation of the Consequences Associated with Audit Committees. Auditing: A Journal of Practice \& Theory, 15, 87-103.

Pana, R. (2010). Ownership Structure in Romanian Listed Companies: a Corporate Governance and Corporate Performance Perspective (Master's Thesis). Retrieved from www.pure.au.dk

Raheja, C. (2005). Determinants of Board Size and Composition: A Theory of Corporate Boards. Journal of Financial and Quantitative Analysis, 40(2), 283-306.

Sedik, T., \& Williams, O. (2011). Global and Regional Spillovers to GCC Equity Markets (Working Paper No. 11/138). Retrieved from https://www.imf.org

Soliman, M. (2013). Ownership Concentration and Firm Financial Performance: Evidence from Saudi Arabia. Retrieved from http://ssrn.com/abstract $=2257832$

Uzun, H., Szewczyk, S. H., \& Varma, R. (2004). Board Composition and Corporate Fraud. Financial Analysts Journal, 60(3), 33-43.

Wang, J., \& Dewhirst, H. (1992). Boards of Directors and Stakeholder Orientation. Journal of Business Ethics, 11(2), $115-123$.

Zheka, V. (2006). Does Corporate Governance Causally Predict Firm Performance? Panel Data and Instrumental Variables Evidence. Paper presented at the March 2006 2nd Annual Conference on Empirical Legal Studies Paper. Retrieved from http://ssrn.com/abstract $=877913$

\section{Appendix}

Table I. Definition of variables

\begin{tabular}{ll}
\hline Variable & Description \\
\hline Tobin's Q & $\begin{array}{l}\text { The ratio of market value of assets to the book value of assets, where the market } \\
\text { value of assets is the book value of assets plus the market value of common equity } \\
\text { less the sum of the book value of common equity and deferred taxes (if any). }\end{array}$ \\
\hline Market-to-Book ratio & Market value of common stock / book value of common stock. \\
\hline Ind $\backslash$ Toal & The percentage of outside board directors to the total number of directors in the firm \\
\hline Ind-comm & $\begin{array}{l}\text { The percentage of outside directors who serve in the Audit and the Nomination and } \\
\text { Remuneration committees to the total number of directors in the firm }\end{array}$ \\
\hline Ind-Aud & $\begin{array}{l}\text { The percentage of outside directors to total number of directors in the Audit } \\
\text { committee }\end{array}$ \\
\hline Ind- Nom and Rem & $\begin{array}{l}\text { The percentage of outside directors to total number of directors in the Nomination } \\
\text { and Remuneration committee }\end{array}$ \\
\hline Chair-Aud & $\begin{array}{l}\text { Binary variable that takes the value of one if the Chairman of the Audit committee is } \\
\text { an outside director, or zero otherwise }\end{array}$ \\
\hline Chair- Nom and Rem & $\begin{array}{l}\text { Binary variable that takes the value of one if the Chairman of the Nomination and } \\
\text { Remuneration committee is an outside director, or zero otherwise }\end{array}$ \\
\hline Size & Natural log of the firm's total assets \\
\hline Leverage & Total leverage of the firm divided by its total assets \\
\hline ROA & The ratio of net income to total assets \\
\hline Invest-opportune & The ratio of capital expenditures to sales \\
\hline FCF & $\begin{array}{l}\text { Operating income before depreciation minus total income taxes, change in deferred } \\
\text { taxes, interest expense, preferred dividends, and dividends on common stock / Total } \\
\text { assets }\end{array}$ \\
\hline Board-Own & The proportion of outstanding shares owned directly by all directors \\
\hline
\end{tabular}

